\title{
Determinant of the Relationship between Natural Gas Prices and Leading Natural Gas Countries' Stock Exchange
}

\author{
Meysam Azizi Kouchaksaraei ${ }^{1}$, Hamed Movahedizadeh ${ }^{2}$ \& Hoda Mohammadalikhani ${ }^{3}$ \\ ${ }^{1}$ Faculty of Management and Economy, Science and Research Branch, IAU Tehran, Iran \\ ${ }^{2}$ Faculty of Economics and Management, University Putra Malaysia, Malaysia \\ ${ }^{3}$ Cardiff School of Management, Cardiff Metropolitan University, London, England \\ Correspondence: Meysam Azizi Kouchaksaraei, Faculty of Management and Economy, Science and Research \\ Branch, IAU Tehran, Iran. Tel: 98-912-6797-481. E-mail: meysamazizi@yahoo.com
}

Received: December 21, 2015

Accepted: March 3, 2015

Online Published: March 25, 2016

doi:10.5539/ijef.v8n4p246

URL: http://dx.doi.org/10.5539/ijef.v8n4p246

\begin{abstract}
Over the recent decades, natural sources of energy have become an interesting topic to investigate for researchers. Sources of energy play a crucial role in all industrial segments such as export revenue, exchange rate and stock market. One of the major sources is natural gas which its price affects many countries' economy. This paper investigates the effect of natural gas price on the three leading natural gas exporting countries' stock market: Russia, Norway and Qatar. This paper employs monthly data observations including natural gas price and stock exchange market index on Russia, Norway and Qatar from January 2005 to November 2013. This study uses Unrestricted Vector Autoregressive model (VAR) to apply Granger Causality test, Impulse Response functions and Variance Decomposition. Findings show that there are two-way causality relationship between natural gas prices and stock exchanges of Russia and Norway, though natural gas prices affected Russia stock exchange index at $10 \%$ significance level and Norway stock exchange index at 5\% significance. However, there is not causality relationship between Qatar stock exchange and natural gas prices. Moreover, outcomes of impulse response function present that natural gas price shock does not have significant impact on all three countries' stock exchange. The variance decomposition test also reinforces the results from impulse response function since Russia, Norway and Qatar's stock exchange variance are not significantly due to natural gas price.
\end{abstract}

Keywords: natural gas price, stock exchange, unrestricted vector autoregressive, VAR, Russia, Qatar, Norway

\section{Introduction}

Nowadays, stock exchange market is one of the major parts of economy in developing and developed countries which channel capital between companies and investors. Having the knowledge about stock market behavior can significantly help individuals and investors to make better decision for either selling or buying particular portfolio shares in particular periods. It was proven by Chen et al. (1986) stock prices are sensitive to the news about the state of the economy and are affected by different anticipated events. Generally, there are systematic and unsystematic factors that affect stock market returns. Those factors that relates to a particular portfolio called unsystematic risks which can be monitored through companies' performance such as financial ratios. Unsystematic risks can be controlled and reduced by diversification, while systematic risks cannot be diversified. In fact, systematic risks are not predictable such as macroeconomic factors including oil price, natural gas price, inflation rate, exchange rate and so on.

Investigating the impact of macroeconomic factors on countries' economy has been a popular topic for researchers. Many researches have been conducted to investigate the effect of oil price on countries economy. Al-Rjoub (2005) investigated the effect of changing in oil price on the United States' stock market from 1985 to 2004. Al-Mulali and Che Sab (2010) also estimated reaction on Qatar macroeconomic variables from 1970 to 2007.

However, very few researches have been investigated about the effect of natural gas price on the stock exchange market. This paper focuses on the stock exchange market of the three main countries leading in natural gas export including Russia, Norway and Qatar. 
Table 1. Exports of dry natural gas (Billion Cubic Feet)

\begin{tabular}{lccccccc}
\hline Country & 2006 & 2007 & 2008 & 2009 & 2010 & 2011 & 2012 \\
\hline Norway & 2974.229 & 3011.663 & 3380.352 & 3433.324 & 3561.518 & 3435.796 & 3791.136 \\
Qatar & 1097.943 & 1536.203 & 2005.186 & 2408.13 & 3778.705 & 4015.316 & NA \\
Russia & 8401.792 & 8187.076 & 8380.25 & 7122.682 & 7933.515 & 7808.147 & NA \\
\hline
\end{tabular}

Based on the recent U.S. Energy Information Administration (EIA) statistics presented in table1, Russia was the main natural gas exporter followed by Norway and Qatar in 2011. The data were not available for 2012 and 2013 but these trends probably continued until 2013. This paper tends to investigate the impact on natural gas price shock by looking at stock exchange market of these three countries.

\section{Literature Review}

Several researches have investigated the impact of macroeconomic factors of stock exchange market in different developed and developing countries. Park and Ratti (2008) investigated the impact of oil price shocks on stock exchange returns in U.S.A and 13 European countries from 1986 to 2005 by using VAR model. Their results showed that oil price shocks had effect on stock exchange returns, for instance, increasing oil price in Norway caused stock returns to go up.

Arouri et al. (2010) looked into the relationship between oil price shock and stock returns of Gulf Cooperation Council (GCC) countries through using linear and non-linear models from 2005 to 2008. Their results presented that oil price shocks affected stock returns in Qatar, United Arab Emirates, Saudi Arabia and Oman, while stock returns in Bahrain and Kuwait had not responded to changes in oil prices. Samuel (2010) examined the effect of oil price on stock markets in Mexico, Saudi Arabia, India, china, Russia and the US by using VAR model within the period of 2000-2010. The results revealed that there was one long-term relationship (Mexico inconclusive) in India, China, Saudi Arabia and the US, though there were two long-term relationships in Russia. In addition, according to impulse response and variance decomposition tests oil prices had effect on stock prices in all six countries. Narayan and Nayaran (2010) investigated the relationship between Vietnam's stock prices and oil prices by employing Johansen test from 2000 to 2008. Based on the results, exchange rate and oil prices had a positive and significant long-run effect on Vietnam's stock prices.

Ayhan (2011) examined long-term relationship and short-term dynamics between oil price and Istanbul Stock Exchange from 2000 to 2010 by using Vector Error Correction Model (VECM). He concluded that there was a co-integrated relationship between stock index and oil price. His analysis showed that there was one way causality relationship from stock index to oil price while oil price was not causal of stock index. Arouri and Rault (2011) concluded that there is a positive relationship between stock market returns and oil price shocks for the oil-exporting countries. Filis et al. (2011) showed that demand-side shocks seem to impact on stock returns, whereas supply-side do not seem. Moreover, Basher et al. (2012) concluded that demand oil price shocks have a positive impact on emerging stock markets, whereas supply-side oil price shocks do not have effect.

Hamed et al. (2014) investigated the impact of macroeconomic factors on Tehran stock exchange market within the period of 2006 to 2012. The evidences showed that there is a long-run relationship between macroeconomic factors (Oil price, Gold price, Supplied oil by Iran, Consumer Price Index) and stock exchange market index.

Furthermore, some studies evaluated natural gas prices shocks and its effect in different countries' economic activities. Leone's (1982) investigated the relationship between natural gas price and regional economic activities, particularly in the Northeast region of the US. In addition, Ott and Tatom (1982) showed that there is a temporary effect of natural gas price on inflation. Andersen and Faris (2002) investigated natural gas export during the natural gas boom in Bolivina. Kubo (2010) also investigated the impact of natural gas export on the Myanmar economy. Natural gas is one of the main resources of government revenue in many countries. This dependency is less for developed countries in comparison with developing countries due to their other economic activities.

This paper examines the effect of natural gas prices on stock market exchange of three main natural gas exporter countries: Russia, Norway and Qatar.

\section{Research Methodology}

This paper employs monthly data from January 2006 to November 2013. Natural gas prices are obtained from indexmundi.com. For Qatar, monthly general index of stock exchange market is collected from Qatar's central bank report. Additionally, average monthly closed indices are gathered from Norway and Russia stock exchange websites. All variable are converted into natural logarithm. 
In order to examine the relationship between natural gas prices and stock exchange indices on the three countries, an Unrestrictive Vector Autoregressive model (VAR) is employed. This model explains that changes in one particular variable are resulted from changes in its own lags or from changes in other variables and the lag of those variables. Many studies has employed Vector Error Correction Model (VECM) as there was co-integration between variables, however, Hoffman and Rasche (1996) explained that VAR model would perform better that VECM when a study investigate a short sample in the short term. Similarly, Engle and Yoo (1987) and Celements and Hendry (1995) showed that using unrestricted VAR model results to get more accurate forecast variance than restricted VECM when the true restriction is imposed. As the sample of this study is almost short unrestricted VAR model is employed.

This paper, first of all, investigates the choice of lag criteria as it is very important in unrestricted VAR model. Then, time series data would be tested to examine whether data are stationary or not. After that, descriptive statistics, correlation analysis and Granger Causality test, impulse response function and variance decomposition would be examined and explained.

\subsection{Lag Order Selection}

Before using unrestricted VAR model, choice of lag criteria is important. There are many criteria used in the lag order selection procedure including sequential modified test (LR), Final prediction error (FPE), Akaike information criterion (AIC) Hannan-Quinn information criterion (HQ) and Schwarz information criterion (SC). Since four out of five criteria indicate that lag one is the most proper one for the data, this study chooses lag one for the next tests.

Table 2. Lag order criteria

\begin{tabular}{lllllll}
\hline Lag & LogL & LR & FPE & AIC & SC & HQ \\
\hline 0 & 385.1625 & NA & $1.84 \mathrm{e}-09$ & -8.762356 & -8.648981 & -8.716703 \\
1 & 759.3212 & 705.3106 & $4.89 \mathrm{e}-13^{*}$ & $-16.99589^{*}$ & $-16.42901^{*}$ & $-16.76763^{*}$ \\
2 & 774.2334 & 26.73915 & $5.02 \mathrm{e}-13$ & -16.97088 & -15.95051 & -16.56001 \\
3 & 782.0401 & 13.28042 & $6.10 \mathrm{e}-13$ & -16.78253 & -15.30866 & -16.18905 \\
4 & 793.6121 & 18.62165 & $6.83 \mathrm{e}-13$ & -16.68074 & -14.75336 & -15.90464 \\
5 & 805.0219 & 17.31135 & $7.73 \mathrm{e}-13$ & -16.57522 & -14.19434 & -15.61651 \\
6 & 819.9919 & 21.33653 & $8.14 \mathrm{e}-13$ & -16.55154 & -13.71716 & -15.41022 \\
7 & 848.9471 & $38.60693^{*}$ & $6.29 \mathrm{e}-13$ & -16.84936 & -13.56148 & -15.52543 \\
8 & 865.3313 & 20.33899 & $6.58 \mathrm{e}-13$ & -16.85819 & -13.11681 & -15.35165 \\
\hline
\end{tabular}

* indicates lag order selected by the criterion.

LR: sequential modified LR test statistic (each test at 5\% level).

FPE: Final prediction error.

AIC: Akaike information criterion.

SC: Schwarz information criterion.

HQ: Hannan-Quinn information criterion.

\subsection{Unit Root Test}

It is generally proven that non-stationary data result to wrong interpretation in analyzing time series data, therefore, this paper initially examines unit root test through Augmented Dickey Fuller (ADF) test given by Dickey and Fuller (1979).

Table 3. Unit root test (Level)

\begin{tabular}{ll}
\hline Variable & t-statistic \\
\hline Natural gas price & -2.475514 \\
Russia Stock Index & -2.640320 \\
Norway Stock Index & -2.179129 \\
Qatar Stock Index & -2.470912 \\
\hline & Critical Value \\
\hline $1 \%$ level & -4.059734 \\
$5 \%$ level & --3.458856 \\
$10 \%$ level & -3.155470 \\
\hline
\end{tabular}


Table 4. Unit root test (First difference)

\begin{tabular}{ll}
\hline Variable & t-statistic \\
\hline Natural gas price & -6.342925 \\
Russia Stock Index & -4.925238 \\
Norway Stock Index & -5.403667 \\
Qatar Stock Index & -6.549686 \\
\hline & Critical Value \\
\hline $1 \%$ level & -4.060874 \\
$5 \%$ level & -3.459397 \\
$10 \%$ level & -3.155786 \\
\hline
\end{tabular}

Based on the results of table3, all variables are not stationary in their levels since their t-statistic is greater than critical values; however, table 4 shows that when their first degree differences are taken they become stationary. Therefore, this paper proceeds to examine tests.

\subsection{Granger Causality Test}

In order to determine the direction of the relationship between the variables Granger Causality test is employed given by Granger (1969). To examine the direction of causality the following model has been estimated:

$$
\begin{aligned}
& \mathrm{Y}=\alpha 0+\sum_{i=1}^{k 1} \alpha \mathrm{i} \mathrm{Yt}-\mathrm{i}+\sum_{i=1}^{k 2} \beta \mathrm{iXt}-\mathrm{i}+\varepsilon \mathrm{t} \\
& \mathrm{Xt}=\mathrm{x} 0+\sum_{i=1}^{k 3} x \mathrm{i} \mathrm{Xt}-\mathrm{i}+\sum_{i=1}^{k 4} \delta \mathrm{i} \mathrm{Yt}-\mathrm{i}+v \mathrm{t}
\end{aligned}
$$

According to this model, lag length is indicated by $\mathrm{k}$. If all of the coefficients in the second equation are meaningful totally, and all of the coefficients in the first equation are meaningless, then it is said that there is a one-way causality from $\mathrm{Y}$ to $\mathrm{X}$.

Table 5. Pairwise Granger Causality tests

\begin{tabular}{lcl}
\hline Null Hypothesis: & F-Statistic & Prob. \\
\hline LNN does not Granger Cause LNR & 1.94248 & 0.1668 \\
LNR does not Granger Cause LNN & 1.65178 & 0.2020 \\
LNQ does not Granger Cause LNR & 9.25818 & 0.0031 \\
LNR does not Granger Cause LNQ & 12.6800 & 0.0006 \\
LNG does not Granger Cause LR & 3.13299 & 0.0801 \\
LR does not Granger Cause LNG & 5.20123 & 0.0249 \\
LQ does not Granger Cause LN & 2.99426 & 0.0869 \\
LN does not Granger Cause LQ & 10.3434 & 0.0018 \\
LNG does not Granger Cause LN & 4.45546 & 0.0375 \\
LN does not Granger Cause LNG & 4.63802 & 0.0339 \\
LNG does not Granger Cause LQ & 1.02165 & 0.3148 \\
LQ does not Granger Cause LNG & 0.75490 & 0.3872 \\
\hline
\end{tabular}

The results of the Granger Causality test shown in Table 5 present that natural gas prices affected Russia stock exchange index at $10 \%$ significance level, while Russia stock exchange index affected natural gas prices at $5 \%$ significance level. Whereas natural gas prices and Norway stock exchange index have two-way causality relationship with each other at 5\% significance level, there is not any causality relationship between natural gas prices and Qatar stock exchange index. In addition, it is shown that Qatar has causality relationship with both Norway and Russia's stock exchange index, whereas Norway stock exchange index and Russia stock exchange index does not have any causality relationship with each other.

\subsection{Impulse Response Function}

This paper tends to evaluate how the countries' stock exchange market indexes respond to an impulse of natural gas price shock. When both standard error bands are above or below zero on the y-axis the impulse response function is statistically significant. Impulse response functions (IRF) are taken from one standard deviation shock at $95 \%$ confidence level.

As can be clearly seen from Figure 1, 2 and 3, natural gas price shock affects all three countries' stock exchange but not significantly. In the case of Russia and Norway, responses of stock indexes to the natural gas price shock 
are initially positive but gradually they become negative. However, based on the figure3, response of Qatar stock index is totally negative.

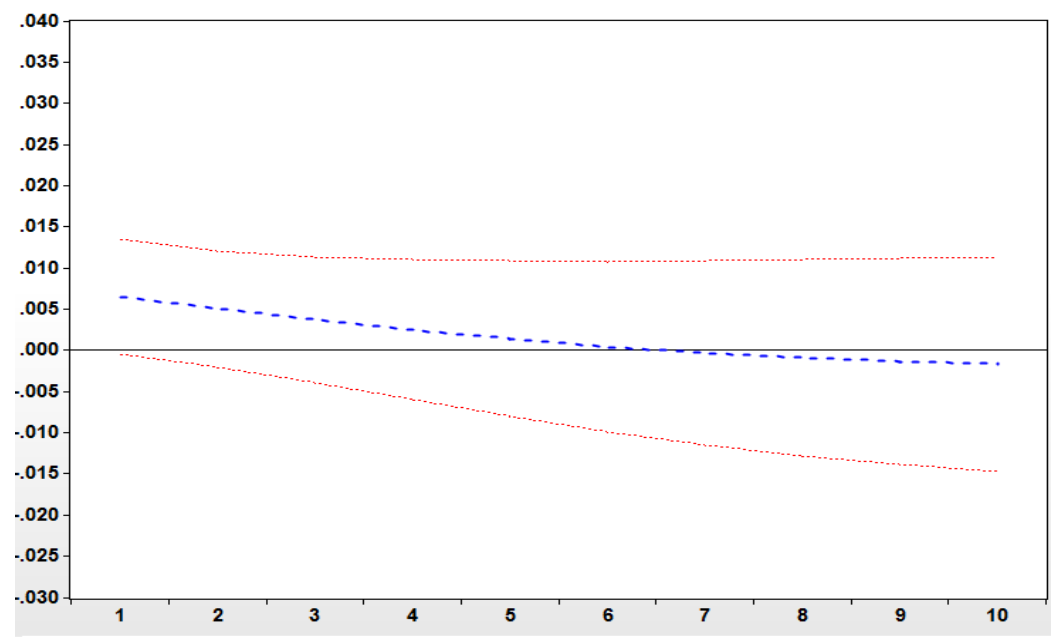

Figure 1. Response of Russia stock index to an impulse of natural gas price shock

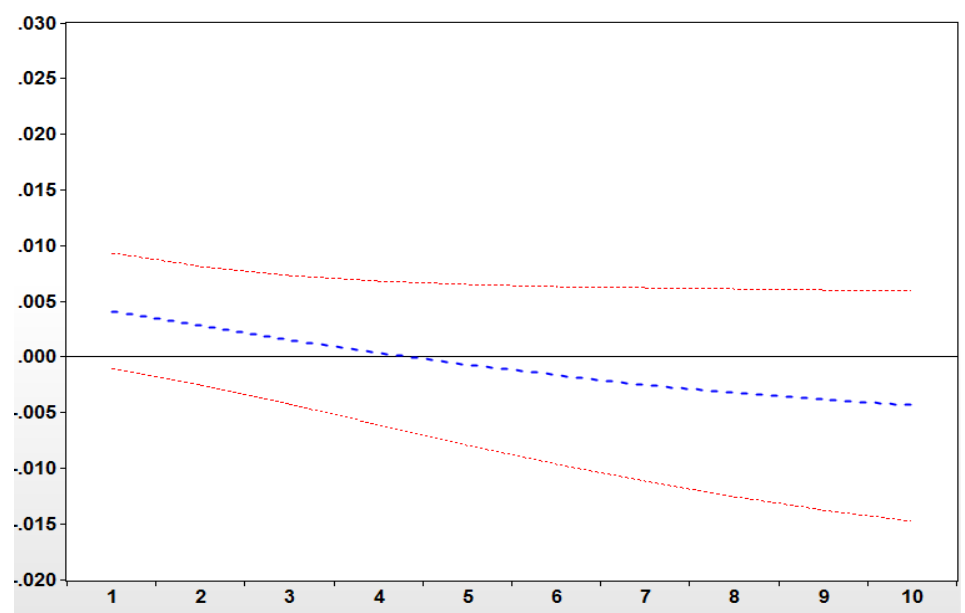

Figure 2. Response of Norway stock index to an impulse of natural gas price shock

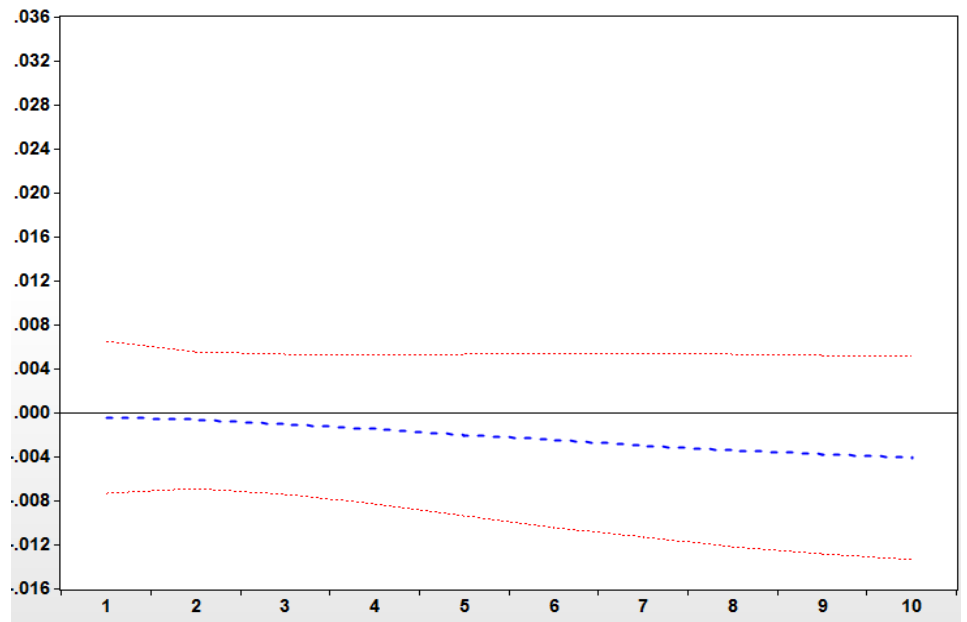

Figure 3. Response of Qatar stock index to an impulse of natural gas price shock 


\subsection{Variance Decomposition}

The purpose of variance decomposition test in this paper is to identify the portion of movement in the stock exchange index variance which is due to its own shocks versus shocks to other stock markets and natural gas prices. As can be seen from Figures 4, 5 and 6, none of the three countries' stock exchange index variance is due to natural gas prices significantly.

Based on the data from Table 6, in the first period, the impact of natural gas price is greater on Russia stock market followed by Norway, while for Qatar stock market it is much lower. However, this impact for Russia and Norway decrease until tenth period, conversely, for Qatar it increases until the last period illustrated.

Table 6. Percent stock exchange index variance due to natural gas price

\begin{tabular}{llcc}
\hline Period & Russia & Norway & Qatar \\
\hline 1 & 3.523691 & 2.626511 & 0.018824 \\
2 & 2.947834 & 1.956695 & 0.039265 \\
3 & 2.464108 & 1.464744 & 0.080635 \\
4 & 2.075913 & 1.138610 & 0.153028 \\
5 & 1.777889 & 0.963827 & 0.265441 \\
6 & 1.559991 & 0.924989 & 0.424099 \\
7 & 1.410078 & 1.006549 & 0.631642 \\
8 & 1.315450 & 1.193191 & 0.887123 \\
9 & 1.263744 & 1.469959 & 1.186535 \\
10 & 1.243462 & 1.822257 & 1.523554 \\
\hline
\end{tabular}

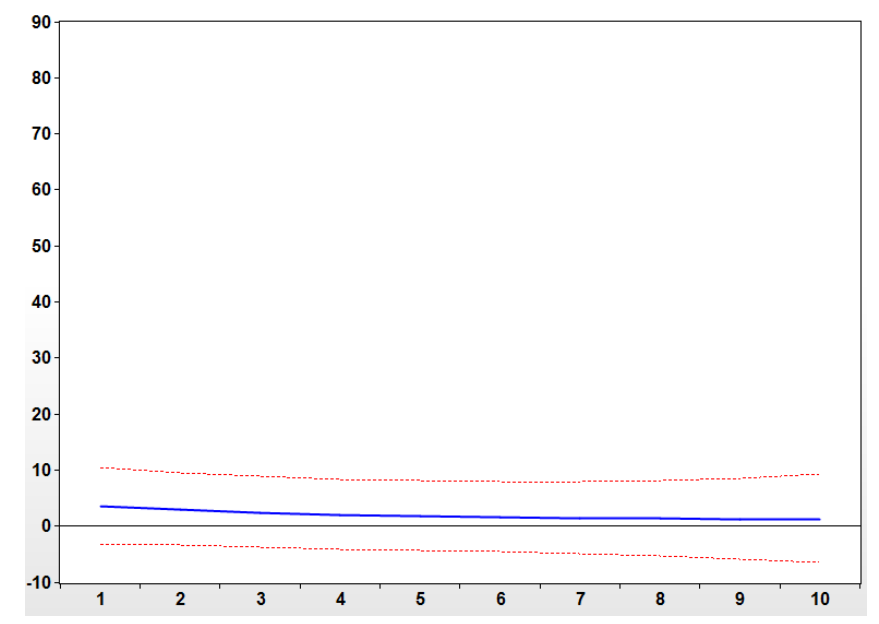

Figure 4. Percent LR variance due to LNG

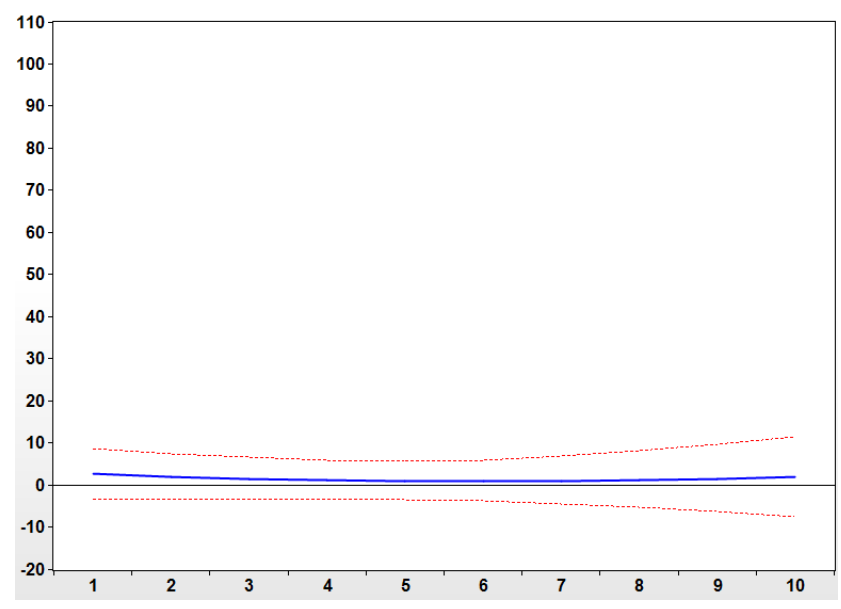

Figure 5. Percent LN variance due to LNG 


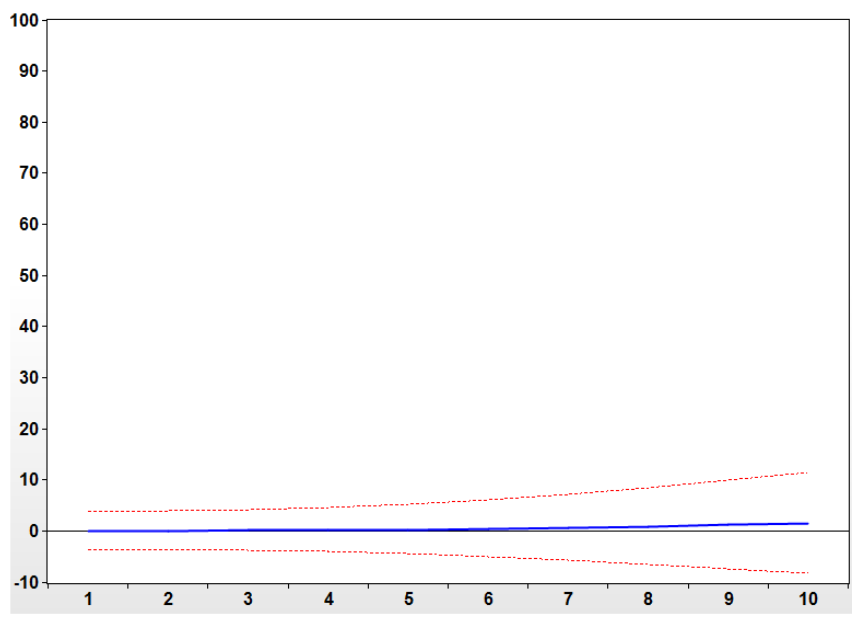

Figure 6. Percent LQ variance due to $\mathrm{LNG}$

\section{Conclusion}

To put it in a nutshell, this paper has investigated the effect of natural gas prices on the stock exchange of three major natural gas exporters: Russia, Norway and Qatar. In order to employ Unrestrictive Vector Autoregressive model (VAR) correctly this paper found through lag order criteria that the proper lag is one. Also, it is resulted that all the variables are stationery at their first differences.

Based on the results of Granger causality test, Russia and Norway stock exchanges have two-way causality relationship with natural gas prices, although natural gas prices affected Russia stock exchange index at $10 \%$ significance level and Norway stock exchange index at 5\% significance. In addition, Qatar does not have causality relationship with natural gas prices. However, results of impulse response function indicate that natural gas price shock affects all three countries' stock exchange insignificantly. The variance decomposition test reinforces the finding from impulse response function since Russia, Norway and Qatar's stock exchange variance are not significantly due to natural gas price.

\section{References}

Al-mulali, U., Sab, C., \& Normee, C. (2010). The Impact of Oil Shocks on Qatar's GDP (No. 27822). University Library of Munich, Germany.

Al-Rjoub, S. A. (2005). Effect of Oil Price Shocks in the US for 1985-2004, using VAR, Mixed Dynamic and Granger Causality Approaches. Applied Econometrics and International Development, 5(3).

Andersen, L. E., \& Faris, R. (2002). Natural gas and income distribution in Bolivia (Vol. 1). Instituto de Investigación Socio Económicas, Universidad Católica Boliviana.

Arouri, M. E. H., Lahiani, A., \& Bellalah, M. (2010). Oil price shocks and stock market returns in oil-exporting countries: The case of GCC countries.International Journal of Economics and Finance, 2(5), 132. http://dx.doi.org/10.5539/ijef.v2n5p132

Basher, S. A., Haug, A. A., \& Sadorsky, P. (2012). Oil prices, exchange rates and emerging stock markets. Energy Economics, 34(1), 227-240. http://dx.doi.org/10.1016/j.eneco.2011.10.005

Chen, N. F., Roll, R., \& Ross, S. A. (1986). Economic forces and the stock market. Journal of Business, 383-403. http://dx.doi.org/10.1086/296344

Clements, M. P., \& Hendry, D. F. (1995). Forecasting in cointegrated systems. Journal of Applied Econometrics, 10(2), 127-146. http://dx.doi.org/10.1002/jae.3950100204

Dickey, D. A., \& Fuller, W. A. (1979). Distribution of the estimators for autoregressive time series with a unit root. Journal of the American Statistical Association, 74(366a), 427-431. http://dx.doi.org/10.1080/01621459.1979.10482531

El hedi Arouri, M., \& Rault, C. (2009). On the influence of oil prices on stock markets: Evidence from panel analysis in GCC countries (No. 2690). CESifo Group Munich.

Engle, R. F., \& Yoo, B. S. (1987). Forecasting and testing in co-integrated systems. Journal of Econometrics, 


\section{5(1), 143-159. http://dx.doi.org/10.1016/0304-4076(87)90085-6}

Filis, G., Degiannakis, S., \& Floros, C. (2011). Dynamic correlation between stock market and oil prices: The case of oil-importing and oil-exporting countries. International Review of Financial Analysis, 20(3), 152-164. http://dx.doi.org/10.1016/j.irfa.2011.02.014

Granger, C. W. (1969). Investigating causal relations by econometric models and cross-spectral methods. Econometrica: Journal of the Econometric Society, 424-438. http://dx.doi.org/10.2307/1912791

Hamed, M., Annuar, M. N., Meysam, A. K., Mehdi, K., Navid, S. S., \& Ehsan B. (2013). The impact of macroeconomic factors on Tehran Stock Exchange Index during unjust economic and oil sanctions from January2006 to December2012. WSEAS Recent Advances in Economics, Management and Marketing.

Hoffman, D. L., \& Rasche, R. H. (1996). Assessing forecast performance in a cointegrated system. Journal of Applied Econometrics, 11(5), 495-517.

Imarhiagbe, S. (2010). Impact of oil prices on stock markets: Empirical evidence from selected major oil producing and consuming countries. Global Journal of Finance and Banking Issues, 4(4), 15.

Kapusuzoglu, A. (2011). Relationships between oil price and stock market: An empirical analysis from Istanbul Stock Exchange (ISE). International Journal of Economics and Finance, 3(6), 99. http://dx.doi.org/10.5539/ijef.v3n6p99

Kilian, L., \& Park, C. (2009). The impact of oil price shocks on the us stock market. International Economic Review, 50(4), 1267-1287. http://dx.doi.org/10.1111/j.1468-2354.2009.00568.x

Kubo, K. (2011). Natural gas export revenue, fiscal balance and inflation in Myanmar. ASEAN Economic Bulletin, 374-387. http://dx.doi.org/10.1355/ae28-3f

Leone, R. (1982). Impact of higher natural gas prices on the northeast regional economy. Contemporary Economic Policy, 1(1), 1-8. http://dx.doi.org/10.1111/j.1465-7287.1982.tb00749.x

Mohammad, A., Amin, A., \& Meysam, A. K. (2016). Design \& Development the IMC Model for Chain Store. International Journal of Business and Management, 11(5).

Narayan, P. K., \& Narayan, S. (2010). Modelling the impact of oil prices on Vietnam's stock prices. Applied Energy, 87(1), 356-361. http://dx.doi.org/10.1016/j.apenergy.2009.05.037

Ott, M., \& Tatom, J. A. (1982). Are there adverse inflation effects associated with natural gas decontrol? Contemporary Economic Policy, 1(1), 27-46. http://dx.doi.org/10.1111/j.1465-7287.1982.tb00751.x

Park, J., \& Ratti, R. A. (2008). Oil price shocks and stock markets in the US and 13 European countries. Energy Economics, 30(5), 2587-2608. http://dx.doi.org/10.1016/j.eneco.2008.04.003

\section{Copyrights}

Copyright for this article is retained by the author(s), with first publication rights granted to the journal.

This is an open-access article distributed under the terms and conditions of the Creative Commons Attribution license (http://creativecommons.org/licenses/by/3.0/). 